\title{
Enabling Elements for the Implementation of Community Health Promoter Led Interventions: A Literature Review
}

\author{
Elementos Habilitadores para la Implementación de Intervenciones Dirigidas \\ por Promotores de Salud Comunitaria: Una Revisión de la Literatura
}

\author{
Paola Olave-Müller'; Natalia López-Contreras²; Gabriel Cirano-Méndez; \\ Etienne Duim ${ }^{3}$ \& Javiera Muñoz-Mardones ${ }^{1}$
}

OLAVE-MÜLLER, P.; LÓPEZ-CONTRERAS, N.; CIRANO-MÉNDEZ, G.; DUIM, E. \& MUÑOZ-MARDONES, J. Enabling elements for the implementation of community health promoters led interventions: A Literature Review. Int. J. Odontostomat., 12(4):437-444, 2018.

ABSTRACT: This research seeks to present Community Lay Advisor interventions as a health promoting strategy that have appeared in the international literature, in order to highlight these enabling elements in the intervention's implementation and establish a comparison among the aspects addressed in the analyzed experiences and the "Schoolbased Oral Health Promoters Program" at the Universidad de La Frontera in Temuco, Chile. A comprehensive scoping review was held between February and March 2018, with searches performed in both the academic and grey literature. Peer-reviewed scientific papers were found using the interdisciplinary database Scopus (including MEDLINE) and EBSCOhost, while grey literature and media sources were extracted from the Google and Google Scholar search engines, supplemented with a visit to the EPES foundation in Chile and an analysis of the reference lists for the selected articles. 369 articles were identified, of which 23 met eligibility criteria for this review. Based on the analysis of the experiences, some facilitators were found more pertinent when achieving the goals concerning the intervention's design, implementation and assessment. This paper makes recommendations for the design and execution of peer-led health promotion interventions in order to increase its effectiveness and success rate.

KEY WORDS: community health promoters, health promotion, community health, health literacy, peer-led education.

\section{INTRODUCTION}

Globally, non-communicable diseases (NCD) currently account for nearly $75 \%$ of adult mortality. The present health outlook discloses the epidemiological transition that developed and developing nations are facing.

These medical conditions - such as cardiovascular diseases, metabolic syndrome, tooth decay, periodontopathies, obesity and certain cancers - are related to lifestyle and prolonged exposure to modifiable behaviors like malnutrition, smoking and physical inactivity (al-Maskari, 2010).

The emerging epidemic emanating from the rising prevalence of NCD in developed countries, establishes among its determinants social, economic, environmental and cultural factors, as well as globalization, urbanization and

${ }^{1}$ Dental School, Universidad de La Frontera, Temuco, Chile.

2 Universidad Pompeu Fabra, Barcelona, España.

${ }^{3}$ School of Public Health, University of São Paulo, São Paulo, Brasil. demographic transitions. Conversely, the sanitary system in the region maintains its focus on assistentialism which has not achieved an efficient response to the current health issues of the most vulnerable populations and territories (Ministerio de Salud Pública y Asistencia Social, 2015).

Faced with this scenario, the actions undertaken in the primary prevention levels, together with the social protection systems and the programs with social determinants of health approach, are key elements due to their potential to mitigate the risk factors of diseases that represent a threat and to avoid an increase in their incidence in a timely fashion.

Considering that the primary focus is to avoid or delay disease outbreak, this primary levels perform preventive and educational activities that, in terms of health promotion, 
provide tools on an individual and collective level to improve the health situation of people by increasing their control over certain social determinants (World Health Organization, 1986). Thus, health promotion becomes a mediation strategy between the person and their environment by combining educational, political, legislative and organizational support that seeks to construct a healthier future for people and communities (Watt, 2005; Martínez Rodríguez et al., 2008).

Martínez et al. present four different strategies in the context of health promotion, with the Influence Strategy based on the premise of positively predisposing the individuals towards attitudes that represent protective factors for health, through the distinctive elements of effective communication and using informative sources perceived as peers (Martínez Rodríguez et al.).

This strategy upholds the main principles of health literacy through peer educators and is related to the "Social Learning Theory". According to this theory, an individual is able to generate identification synergies alongside those with whom they share common characteristics, in such a way that peer influence over behavior is potentially greater than that of an "expert". Moreover, the cultural relevance of Health Promoters regarding their fellow students allows them to establish close reciprocal relations within the community. This is due to the existence of friendly ties and a common code, enabling them to execute culturally appropriate and cost effective health promotion activities as well as interventions on health education and prevention (Mellanby et al., 2000; Ayala et al., 2010; Josiah Willock et al., 2015).

A Health Promoter, Community Health Agent or Community Lay Advisor is an active community member who performs actions that promote health in their community and whose role is to be a change agent who advocates for the collective health, characterized by receiving adequate formal or informal training as well as support from the health system, without necessarily becoming a party of it (EPES \& DIVAP, 2016).

The "School-based Oral Health Promoters Program" (Programa de Formación de Monitores Escolares en Salud Oral), has been implemented since 2007 by the Dentistry department at Universidad de La Frontera in Temuco, Chile as a part of the academic curriculum during the final two semesters of undergraduate program. Throughout its 10 years of existence, this program has trained more than a thousand Oral Health Promoters across 80 educational institutions from 20 communes in southern Chile, preparing these Community Health Agents in a school setting which leads to the promotion of health actions that are culturally relevant to their community. Established as a promotional tool for healthy lifestyles and the prevention of prevalent oral pathologies, this program contributes to the incipient educational component that the sanitary system provides to the schooling population (Huanquilef et al., 2016).
This peer-led promotional strategy is developed in school age children ( 7 to 12 years of age), since the literature indicates that the most prevalent oral pathology, tooth decay, has a reversible management nature during early childhood and adolescence (Rodríguez Llanes et al., 2009; MINSAL, 2017).

This literature review sought to analyze the enabler elements in peer-led health promotion interventions that have appeared in the literature; and with it, contrast those experiences with the "School-based Oral Health Promoters Program" from the Universidad de La Frontera (Chile) based on five interest criteria.

\section{MATERIAL AND METHOD}

A comprehensive scoping review of previously published articles, media sources and grey literature was performed between February and March 2018 (Arksey \& O'Malley, 2005; Guirao Goris, 2015). Key search terms were "Monitor de Salud"/"Community Lay Advisors" OR "Community Health Promoters", "Escuelas Promotoras de Salud"/"Health Promoting Schools", "Educación Mediada por Pares"/“Peer Led Education”, "Promoción de salud"/“Health Promotion", and "Alfabetización en Salud"/"Health Literacy". Spanish and English articles were considered. No limits were placed on publication dates.

All documents with insufficient data for author and place were excluded, as well as non-relevant articles. Likewise, systematic reviews and studies that made no reference to methodological aspects of communitarian interventions of health promotion and/or health education through peer educators were excluded.

The peer-reviewed scientific papers were searched using the interdisciplinary database Scopus (including MEDLINE) and EBSCOhost.

Grey literature and media sources were extracted from Google and Google Scholar search engines, and supplemented with a visit to the Action Oriented Learning Resources Center (known in Spanish as CREA) from the EPES foundation in Chile and the analysis of reference lists of the selected articles.

All selected experiences were reviewed regarding the enabling elements highlighted by these experiences and compared in accordance with parameters explicitly implied in the selected articles.

\section{RESULTS}

Searching identified 369 articles, of which 301 were excluded due to the absence of direct or indirect reference to community-based and/or educational interventions based 
on peer led education. Full texts of 68 articles were reviewed, of which 20 were excluded on account of a focus on implementer's qualitative perception about Health Promoter programs; 25 articles were excluded as they failed to explore the methodological aspects of the intervention itself or corresponded to a theoretical design that has never been implemented (Fig. 1).

A total of 23 articles met eligibility criteria for this review and were analyzed according to elements that each considered as relevant to the intervention process.

Although all the selected experiences for this review were based on peer educators as health promoters, they are quite heterogeneous regarding processes and approaches to key elements such as intervention permanence over time, monitoring, assessment and origin, among others.

Five parameters were selected as they were continuously presented as enablers in the analyzed studies and at the same time were explicitly mentioned in the experience's operationalization.

These parameters were arranged on a chart (Table I) that allows establishing a parallel among the aspects being addressed by the different health promotion interventions. This type of health promotion strategy becomes necessary to cope with populations wherein social determinants are conditions for their poor health status and healthcare system access. The other 12 programs were oriented toward students (mainly school children) in educational establishments settings, which is a platform that allows continued access to this target group. Understanding that healthy lifestyle and habit acquisition begins during the pre-school age, it is recommended to start training

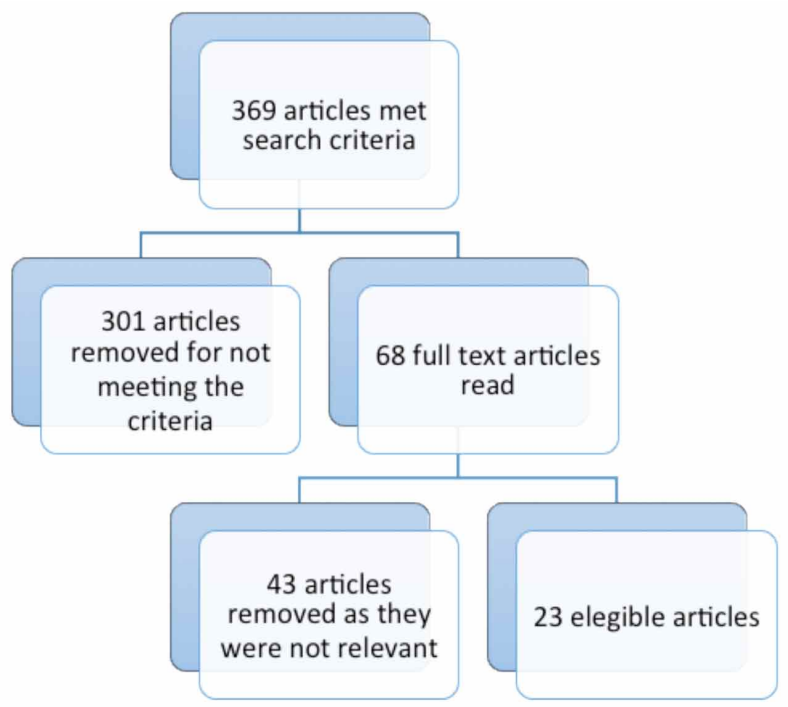

Fig 1. Flow chart of articles meeting search criteria, number of articles excluded and final number of articles meeting inclusion criteria for review. health promoters during pre-school education, integrating a spiral curriculum approach that enables them to strengthen and deepen these topics throughout school years (Booth \& Samdal, 1997; Ministerio de Educación y Deportes, 2017). For this reason, the programs that sought to increase healthy behaviors through school-based education require involvement from parents and caregivers, due to the fact that long-term impactsof the intervention in children are strongly influenced by behaviors and attitudes they observe in their surroundings, determining the overall success rate of the intervention (Booth \& Samdal; Soto Ugalde et al., 2015).

A clear definition of the target audiences for this type of intervention may act as an enabler that may guide actions, strategies and content towards a relevant approach based on the health, social and cultural necessities of a community.

Thus, the importance of conducting culturally relevant actions in the health promotion framework has been widely demonstrated through literature. This is specifically evident in experiences carried out with social minorities where the intervention success rate depends on the proper selection of health promoters who belong to these minorities and/or bilingual speakers who are able to establish open and regular communication that allows them to address the health issues in their community due to the deep knowledge they have about the context, daily actors and the problems faced, as well as taking part in the constitution of a supportive network (Szilágyi, 2002; Ayala et al.; Tran et al., 2014; Hsu et al., 2015).

Regarding the content addressed in analyzed interventions, most deal with issues related to NCD, which is consistent with the current epidemiological profile. Only three experiences considered prevention of communicable diseases such as HIV and Malaria, which makes this equally relevant considering that these diseases represent, for HIV, a global health concern, and in the case of Malaria, a specific problem in the region where the intervention was carried out.

Community participation was a relevant enabler highlighted in the analyzed articles, which is presented by means of varied tools and during the different steps of experience implementation. Some of the most notable examples in this issue are the "Grupo de salud Gabriela Mistral", the "Círculo de Mujeres por la Salud" and the "Students as Lifestyle Activists - SALSA" experiences, wherein the sustainability of a health promoters program was directly related with community involvement, basing interventions on community self-diagnosis in order to mobilize them around their own health interests and necessities (EPES, 1998; Círculo de Mujeres por la Salud, 2000; Shah et al., 2011).

Regarding the health promoter role, the National Community Health Advisor Study identified seven core roles and competencies, highlighting cultural mediation, health education/promotion and the implementation of tangible health actions, so that the main focus of their actions is based on building a connection between community and local health 


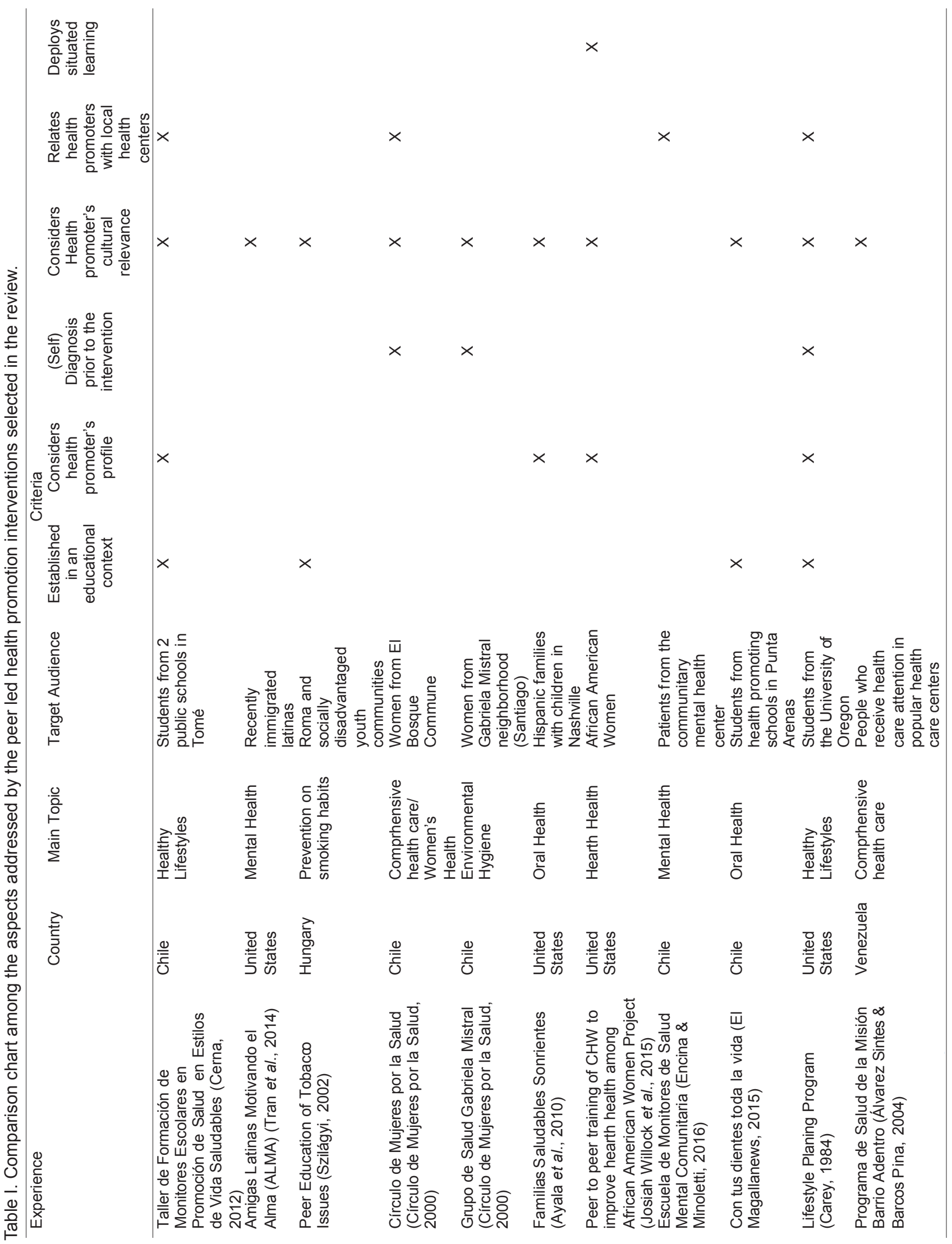




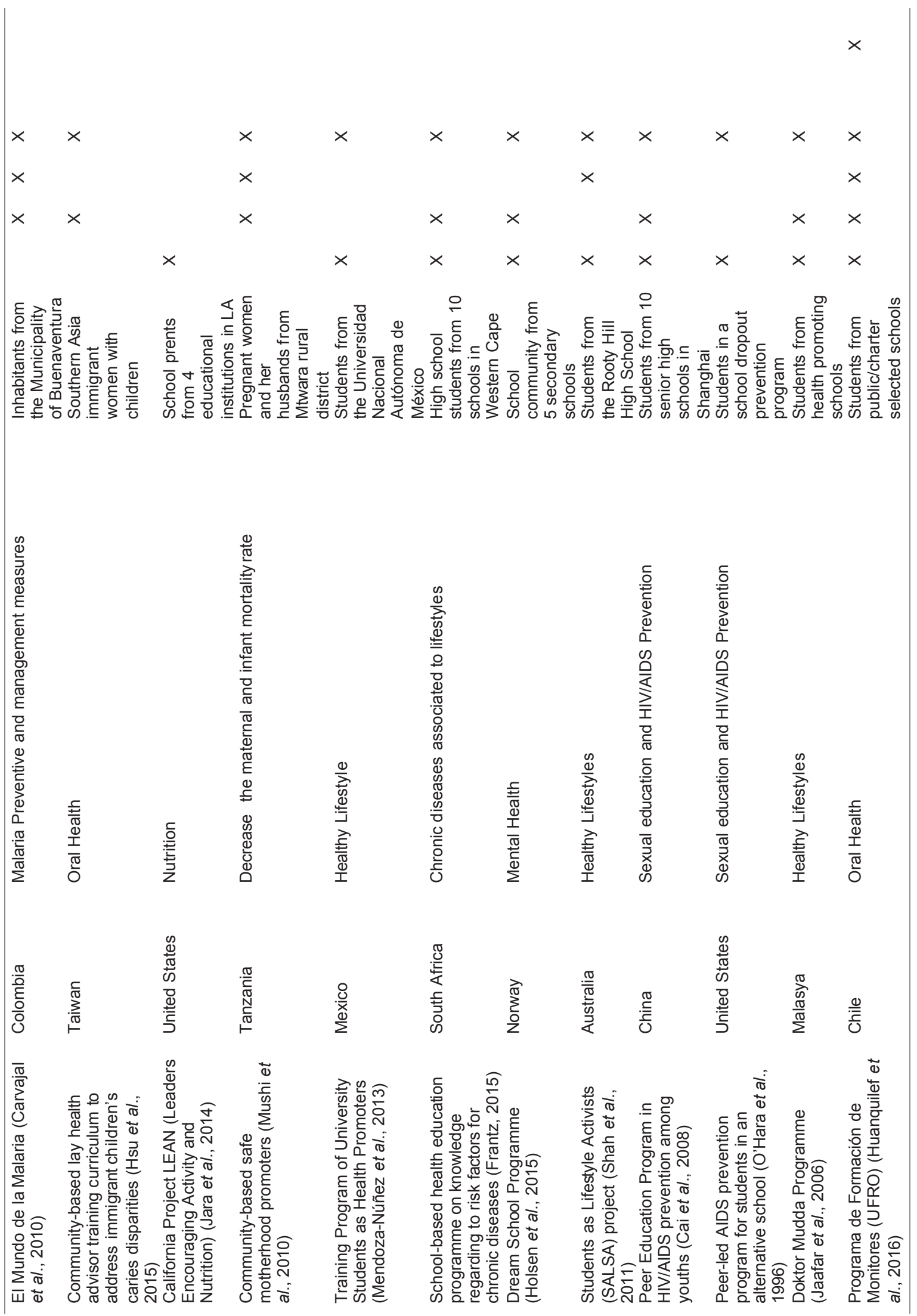


systems. In this way, the "School of Communitarian Mental Health Promoters" (known in Spanish as ESMC), developed in partnership with the Communitarian Mental Health Center located in La Pintana commune (Chile), has an action range that includes prevention and intervention of mental health in the commune's territory, as well as health center decisionmaking and design/implementation of new ESMC versions (Rosenthal, 2000; Encina \& Minoletti, 2016). Similarly, the "Programa de Salud de la Misión Barrio Adentro" trained communitarian health promoters in comprehensive health issues and linked them to the health center through their participation in health worker home visits, individual and group educational activities and identification of risk factors that threaten human health in the territory influenced by this program(Álvarez Sintes \& Barcos Pina, 2004).

In regards to health promoters profile and their selection process, the experience of the "Doktor Muda Programme", implemented on a school setting, highlights the relevance of the rigorous health promoter selection process based on academic and attitudinal criteria (Jaafar et al., 2006). In contrast, the "Taller de Formación de Monitores Escolares en Promoción de Salud en Estilos de Vida Saludables" experience suggests avoiding the selection of school children as health promoters under behavioral and/or academic criteria even when, according to the literature, the peer perception and validation of a health promoter speech may be influenced by their disciplinary background (Mellanby et al.; Cerna, 2012). Similarly, although the "Dream School Programme" has a specific health promoter profile, the program establishes that selected health promoters shall represent a heterogeneous student group in terms of gender and academic performance, giving more value to aspects such as engagement and motivation towards the program and credibility among other students (Holsen et al., 2015). In accordance with this last point, although the "Communitybased safe Motherhood promoters" program has a specific health promoter profile, it prioritizes the personal aptitudes of the candidates, such as charisma, influence and cultural relevance with regard to the group (Mushi et al., 2010).

Regarding the experiences' evaluation, seven of the included articles explicitly mentioned impact assessments about the intervention itself, which differ methodologically. The "Peer Training of Community Health Workers to Improve Heart Health among African American Women" focused its assessment on health promoters trained as implementation partners of the program, evaluating self-confidence levels about the communitarian role, heart health knowledge and satisfaction with the training program (Josiah Willock et al.). Five interventions focused on the community members who got benefited by them. Thus, the "Community-Based Lay Health Advisor Training Curriculum to Address Immigrant Children's Caries Disparities", the "Community-based safe Motherhood promoters" and the "Peer-led school-based HIV/ AIDS prevention among youths", based intervention assessment impact on those aspects related with acquired knowledge, as well as self-efficacy reports with respect to the main subject addressed by the different programs (Cai et al., 2008; Mushi et al.; Hsu et al.). Meanwhile "The World of Malaria" and "Peer led AIDS prevention program for students in an alternative school" evaluated the intervention impact with just one parameter: acquired knowledge and selfefficacy perceived for the risk factor management and exposure leading to the disease, respectively (O'Hara et al., 1996; Carvajal et al., 2010).

"Amigas Latinas Motivando el Alma - ALMA" was the only analyzed experience deploying clinical questionnaires to measure the mental health aspects that were addressed through intervention (presence of depressive symptoms and attitudes about depression and stress) (Tran et al.).

Notably, all the articles that explicitly mentioned intervention impact assessment processes reported the programs as successful experiences based on their settled goals.

For its part, the Universidad de La Frontera's "Schoolbased Oral Health Promoters Program" deployed "situated learning" as a part of the program approach, meaning that the knowledge belongs to and is a product of the activity, context and culture, allowing a bidirectional knowledge flow between the facilitators (dentistry students) who pass knowledge to a communitarian leader who is being trained (school children). The health promoters integrate and translate this knowledge into a code that allows application, replication and promotion to community members (Díaz Barriga Arceo, 2003; Huanquilef et al.). Based on situated learning values, but without being recognized as such, the "Peer to peer training of community health workers to improve heart health among African American women project" deployed highly participative teamwork, generating collective knowledge from the problem solving and experiential learning approach, in order to create individual and collective significances, going beyond the memory to increase understanding and knowledge appropriation (Díaz Barriga Arceo; Josiah Willock et al.).

\section{LIMITATIONS}

Certain limitations of this review should be acknowledged. The experiences of health promoters were not reported in the literature, and therefore were not included in this review.

Since these interventions had specific target audiences and approaches, the similarities among them are based on elements mentioned explicitly in the articles, omitting some others that may also be relevant.

\section{CONCLUSIONS}

The community-based peer-led health promotion programs represent an opportunity to establish a link between communities and local health networks in a permanently fluid 
way allowing to increase culturally relevant codes regarding community requirements to increase sector efficiency.

Thus, the enabling elements highlighted by the Health Promoter Programs are crucial to achieve predetermined goals concerning different intervention stages during the outset, implementation and assessment, including notable ones such as: clear setting of the target audience, based on communitarian contexts; health promoter selection based on a specific profile focused on social skills that potentially validate them as community leaders; participatory nature of the intervention, observed in concrete measures such as the prior communitarian self-diagnosis; and a clear guidance for the program implementers regarding their role as health promoters and specific tasks, identifying their own skills and limitations regarding their scope of action.

On the other hand, it is relevant to implement impact measurement processes as a way to strengthen the health promotion programs and display the effects in short and midterms regarding the predetermined goals.

Also, it is recommended to assess the perception of community health agents in respect to their training and performance as health promoters, which provides valuable feedback about the intervention, making it possible to improve current and subsequent versions.

\section{ACKNOWLEDGMENTS}

The researchers express their sincere respect and gratitude to Mr. Jorge Olivares, Director of the Action Oriented Learning Resources Center from the EPES foundation (Chile), for providing information and internal reports about their own experiences in peer-led education programs.

OLAVE-MÜLLER, P.; LÓPEZ-CONTRERAS, N.; CIRANOMÉNDEZ, G.; DUIM, E. \& MUÑOZ-MARDONES, J. Elementos habilitadores para la implementación de intervenciones dirigidas por promotores de salud comunitaria: una revisión de la literatura. Int. J. Odontostomat., 12(4):437-444, 2018.

RESUMEN: Esta investigación busca presentar las intervenciones del Community Lay Advisor como una estrategia de promoción de la salud que ha aparecido en la literatura internacional, para resaltar estos elementos habilitadores en la implementación de la intervención y establecer una comparación entre los aspectos abordados en las experiencias analizadas y el "Programa de Promotores de Salud Bucal en las Escuelas" de la Universidad de La Frontera, en Temuco, Chile. Entre febrero y marzo de 2018 se llevó a cabo una revisión exhaustiva del alcance, con búsquedas realizadas tanto en la literatura académica como en la gris. Se encontraron artículos científicos revisados por pares utilizando la base de datos interdisciplinaria Scopus (incluyendo MEDLINE) y EBSCOhost, mientras que la literatura gris y las fuentes de medios se extrajeron de los motores de búsqueda Google y Google Scholar, complementados con una visita a la fundación EPES en Chile y un análisis de las listas de referencias de los artículos seleccionados. Se identifi- caron 369 artículos, de los cuales 23 cumplieron con los criterios de elegibilidad para esta revisión. Sobre la base del análisis de las experiencias, algunos facilitadores resultaron más pertinentes al alcanzar los objetivos relacionados con el diseño, la implementación y la evaluación de la intervención. Este documento hace recomendaciones para el diseño y la ejecución de intervenciones de promoción de la salud dirigidas por pares para aumentar su eficacia y su tasa de éxito.

PALABRAS CLAVE: promotores de salud comunitaria, promoción de la salud, salud comunitaria, alfabetización en salud, educación dirigida por pares.

\section{REFERENCES}

Al-Maskari, F. Enfermedades relacionadas con el estilo de vida?: Una carga económica para los servicios de salud. Cron. ONU, 47(2), 2010. Available from: https://unchronicle.un.org/es/article/ enfermedades-relacionadas-con-el-estilo-de-vida-una-cargaecon-mica-para-los-servicios-de

Álvarez Sintes, R. \& Barcos Pina, I. Experiencia en el diseño y la ejecución del programa de formación de promotores comunitarios de salud en el contexto de la misión Barrio Adentro. Rev. Cuba. Med. Gen. Integr., 20(5-6), 2004. Available from: http:// scielo.sld.cu/scielo.php?script=sci_arttext\&pid=S086421252004000500018

Arksey, H. \& O'Malley, L. Scoping studies: towards a methodological framework. Int. J. Soc. Res. Methodol., 8(1):19-32, 2005.

Ayala, G. X.; Vaz, L.; Earp, J. A.; Elder, J. P. \& Cherrington, A. Outcome effectiveness of the lay health advisor model among Latinos in the United States: an examination by role. Health Educ. Res., 25(5):815-40, 2010.

Booth, M. L. \& Samdal, O. Health-promoting schools in Australia: models and measurement. Aust. N. Z. J. Public Health, 21(4):36570, 1997.

Cai, Y.; Hong, H.; Shi, R.; Ye, X.; Xu, G.; Li, S. \& Shen, L. Long-term follow-up study on peer-led school-based HIVIAIDS prevention among youths in Shanghai. Int. J. STD AIDS, 19(12):848-50, 2008.

Carey, M. I. Peer health advisor program to reduce the health risks of university students. Public Health Rep., 99(6):614-20, 1984.

Carvajal, R.; Mosquera, J. \& Carrasquilla, G. The world of malaria: a health educational experience in the Colombian Pacific coast. Colomb. Med., 41(3):240-7, 2010.

Cerna, M. M. Taller formación Monitores Escolares en Promoción de Salud en Estilos de Vida Saludable (CESFAM Bellavista, Tomé). Concepción, Primeras Jornadas Buenas Prácticas en APS y Salud Familiar, Universidad de Concepción, Facultad de Medicina, Departamento de Salud Pública, Programa de Salud y Medicina Familiar, 2012.

Círculo de Mujeres por la Salud. Aprendiendo juntas: Experiencia comunitaria en Talleres de Sexualidad. Serie Apuntes para la Acción, Año 2, Número 4, 2000.

Díaz Barriga Arceo, F. Cognición situada y estrategias para el aprendizaje significativo. Rev. Electron. Investig. Educ., 5(2), 2003. Available from: http://redie.ens.uabc.mx/vol5no2/ contenido-arceo.html

El Magallanews. Programas de Salud Bucal y Salud Joven lanzaron campaña "Con tus dientes toda la vida" en Punta Arenas. Punta Arenas, El Magallanews, 2015. Available from: http:// www.elmagallanews.cl/noticia/sociedad/programas-de-saludbucal-y-salud-joven-lanzaron-campana-con-tus-dientes-toda-lavid 
Encina, E. \& Minoletti, A. Hacia una estrategia de participación en y para la salud mental: escuela de monitores en salud mental comunitaria La Pintana. Rev. Chil. Salud Pública, 20(2):91-100, 2016.

Frantz, J. M. A peer-led approach to promoting health education in schools: The views of peers. S. Afr. J. Educ., 35(1):1040, 2015.

Fundación Educación Popular en Salud (EPES). Dos Experiencias de Formación de Grupos de Salud Poblacional. Serie Apuntes para la Acción, Año 1, Número 1, 1998.

Fundación EPES \& División de Atención Primaria (DIVAP). Manual de Apoyo a la Incorporación de Agentes Comunitarios en Salud en los Equipos de los CECOSF. Santiago de Chile, Fundación EPES, División de Atención Primaria (DIVAP), Subsecretaría de Redes Asistenciales, Ministerio de Salud, Gobierno de Chile, 2016. Available from: http://web.minsal.cl/wp-content/uploads/ 2017/01/Manual-Apoyo-incorporación-ACS-en-Cecosf.pdf

Guirao Goris, S. J. A. Utilidad y tipos de revisión de la literatura. Ene, 9(2), 2015. Available from: http://scielo.isciii.es/ scielo.php?script=sci arttext\&pid=S1988-348X2015000200002

Holsen, I.; Larsen, T.; Tjomsland, H. E. \& Servan, A. K. Exploring the importance of peers as leaders in the Dream School Program: from the perspectives of peer leaders, teachers and principals. Adv. Sch. Ment. Health Promot., 8(1):4-16, 2015.

Hsu, Y. J.; Peng, W. D.; Chen, J. H.; Lin, Y. C.; Chang, C. S.; Chen, T.; Hu, C. Y.; Ho, P. S.; Chen, F. L.; Lee, C. H. \& Huang, H. L. Evaluating the effect of a community-based lay health advisor training curriculum to address immigrant children's caries disparities. Caries Res., 49(2):147-56, 2015.

Huanquilef, M.; Cirano, G. \& Tagle, C. Informe Descriptivo "IX programa de Formación de Monitores en Salud Oral, 2016". Temuco, Facultad de Odontología, Universidad de La Frontera, 2016.

Jaafar, N.; Omar, K.; Ahmad, J.; Wan Hussein, W. S. \& Manaf, Z. A. The "Doktor Muda" health promotion program - A process evaluation. SEAMEO, 2006. Available from: http:// www.seameo.org/vl/library/dlwelcome/projects/jasper/jasper05/ jasper05.htm\#top

Jara, E. A.; Ritterman Weintraub, M.; Clifton-Hawkins, N. \& Martinez, N. Effects of a promotor training on local school wellness advocacy capacity. Health Promot. Pract., 15(1):63-71, 2014.

Josiah Willock, R.; Mayberry, R. M.; Yan, F. \& Daniels, P. Peer training of community health workers to improve heart health among African American women. Health Promot. Pract., 16(1):63-71, 2015.

Martínez Rodríguez, A.; Martínez Rodríguez, E. \& Paz Lourido, B. Estrategias de intervención en promoción de la salud. Fisioterapia, 30(5):238-43, 2008.

Mellanby, A. R.; Rees, J. B. \& Tripp, J. H. Peer-led and adult-led school health education: a critical review of available comparative research. Health Educ. Res., 15(5):533-45, 2000.

Mendoza-Núñez, V. M.; Mecalco-Herrera, C.; Ortega-Ávila, C.; Mecalco-Herrera, L.; Soto-Espinosa, J. L. \& Rodríguez-León, M. A. A randomized control trial: training program of university students as health promoters. B. M. C. Public Health, 13:162, 2013.

Ministerio de Educación y Deportes. Formación de hábitos alimentarios y de estilos de vida saludables. En: Currículo de Educación Inicial. Caracas, Ministerio de Educación y Deportes, República Bolivariana de Venezuela, 2017. pp.331-66. Available from: https://www.unicef.org/venezuela/spanish/educinic9.pdf

Ministerio de Salud (MINSAL). Salud Bucal y Calidad de Vida: Promoción y Prevención en Salud Bucal. Santiago de Chile, Ministerio de Salud (MINSAL), Gobierno de Chile, 2017. Available from: http://saludbucal.minsal.cl/fundamentos-de-salud-bucal/saludbucal-y-calidad-de-vida/

Ministerio de Salud Pública y Asistencia Social. Análisis de la Situación Epidemiológica de Enfermedades No Transmisibles Guate- mala 2015. Ciudad de Guatemala, Ministerio de Salud Pública, República de Guatemala, Centro Nacional de Epidemiología, 2015. Available from: http://epidemiologia.mspas.gob.gt/files/ Publicaciones/Semanas Situacional/asis ent 2015.pdf

Mushi, D.; Mpembeni, R. \& Jahn, A. Effectiveness of community based Safe Motherhood promoters in improving the utilization of obstetric care. The case of Mtwara Rural District in Tanzania. B. M. C. Pregnancy Childbirth, 10:14, 2010.

O'Hara, P.; Messick, B. J.; Fichtner, R. R. \& Parris, D. A peer-led AIDS prevention program for students in an alternative school. J. Sch. Health, 66(5):176-82, 1996.

Rodríguez Llanes, R.; Traviesas Herrera, E. M.; Lavandera Carballido, E. \& Duque Hernández, M. Factores de riesgo asociados con la caries dental en niños de círculos infantiles. Rev. Cuba. Estomatol., 46(2), 2009. Available from: http://bvs.sld.cu/ revistas/est/vol46_2_09/est06209.htm

Rosenthal, E. L. (Ed.). Summary of the National Community Health Advisor Study. A Policy Research Project of the University of Arizona. Washington D. C., The Annie E. Casey Foundation, Harrison Institute for Public Law, Georgetown University Law Center, 2000.

Shah, S.; Patching van der Sluijs, C.; Lagleva, M.; Pesle, A.; Lim, K. S.; Bittar, H. \& Dibley, M. A partnership for health - working with schools to promote healthy lifestyle. Aust. Fam. Physician, 40(12):1011-3, 2011.

Soto Ugalde, A.; Sexto Delgado, N. M. \& Gontan Quintana, N. Intervención educativa en salud bucal en niños y maestros. MediSur, 12(1):24-34, 2015

Szilágyi, T. Peer education of tobacco issues in Hungarian communities of Roma and socially disadvantaged children. Cent. Eur. J. Public Health, 10(3):117-20, 2002.

Tran, A. N.; Ornelas, I. J.; Kim, M.; Perez, G.; Green, M.; Lyn, M. J. \& Corbie-Smith, G. Results from a pilot promotora program to reduce depression and stress among immigrant Latinas. Health Promot Pract., 15(3):365-72, 2014.

Watt, R. G. Strategies and approaches in oral disease prevention and health promotion. Bull. World Health Organ., 83(9):711-8, 2005.

World Health Organization. The Ottawa Charter for Health Promotion. Ottawa, World Health Organization, 1986.

Corresponding author:

Dr. Paola Olave-Müller

Dentistry School

Universidad de La Frontera

Av. Francisco Salazar 01145

Temuco

CHILE

Received: 25-07-2018

Accepted: 07-09-2018

Email: paola.olave@ufrontera.cl 